\title{
Biological properties of the Chilean native moss Sphagnum magellanicum
}

\author{
GLORIA MONTENEGRO ${ }^{*}, 1$, MARIANA C PORTALUPPI ${ }^{1}$, \\ FRANCISCO A SALAS ${ }^{1}$ and MARÍA F DÍAZ ${ }^{2}$
}

\author{
${ }^{1}$ Departamento de Ciencias Vegetales, Facultad de Agronomía e Ingeniería Forestal, Pontificia Universidad \\ Católica de Chile, Avenida Vicuña Mackenna 4860, Macul, Santiago, Chile. \\ ${ }^{2}$ Centro de Estudios Avanzados en Ecología y Biodiversidad, Departamento de Ecología, Pontificia \\ Universidad Católica de Chile, Casilla 114-D, Santiago, Chile. Tel.: 52-02-3545726; fax: 52-02 9-3545726 \\ E-mail: gmonten@uc.cl (G. Montenegro)
}

\begin{abstract}
An ethanol extract prepared from the gametophyte Chilean native moss Sphagnum magellanicum was dried out, weighed and dissolved in distilled water. This extract was then assayed for its antibacterial activity against the G(-) bacteria Azotobacter vinelandii, Erwinia carotovora subsp. carotovora, Enterobacter aerogenes, Escherichia coli, Pseudomonas aeruginosa, Salmonella typhi, Vibrio cholerae, and the G(+) bacteria Staphylococcus aureus subsp. aureus, and Streptococcus type $\beta$. The growth of the cultures of E. carotovora subsp. carotovora, and V. cholerae was inhibited at a concentration of $581 \mu \mathrm{g} / \mathrm{ml}$ of extract, while the cultures of E. coli, S. typhi and Streptococcus type $\beta$ were inhibited at a concentration of $1.16 \mu \mathrm{g} / \mathrm{mL}$ of extract. The concentration of phenolic compounds was $4.294 \mathrm{mg} / \mathrm{mL}$; the presence of vanillic, chlorogenic, syringic, caffeic, gallic, 3-4 hydrozybenzoic, p-coumaric and salicylic acids was identified using RP- High Pressure Liquid Chromatography.
\end{abstract}

Key terms: Sphagnum magellanicum, phenolic compounds, antibacterial activity, MIC.

\section{INTRODUCTION}

The moss species, Sphagnum magellanicum Brid. (Sphagnaceae), in its natural form, is found in Chile from parallels $37^{\circ} 34^{\prime}$ $58.88^{\prime \prime}$ S to $44^{\circ} 02^{\prime} 11.90^{\prime \prime} S$ South Latitude. It grows in extensive areas of an edaphic formation called "ñadi" and in wetlands.

This species has the great ability to absorb and retain water up to twenty times its dry weight, a characteristic that has been utilized for industrial and agricultural purposes (Van Breemen, 1995; Villaroel et al., 2002). It is considered a source of dietary fiber and has other properties as well: regulation of intestinal functioning by reduction of glucose and may also attributes that prevent colon cancer (Atalah et al., 1999). The antimicrobial properties of the ethanol extract have been studied in various species of Sphagnum (Basile et al., 1999) and in the Indian native moss Sphagnum junghuhnianum (Singh et al.,
2006). In relation to these studies, the objective of the present investigation was to study the effects of ethanol extracts of Chilean native moss $S$. magellanicum on the in vitro growth of the $\mathrm{G}(-)$ bacteria: Azotobacter vinelandii, Erwinia carotovora subsp. carotovora, Enterobacter aerogenes, Escherichia coli, Pseudomonas aeruginosa, Salmonella typhi, Vibrio cholerae, and the G(+) bacteria: Staphylococcus aureus subsp. aureus and Streptococcus type $\beta$. Furthermore, the phenolic compounds present in the ethanol extract, which may have antioxidant capacity, were also studied.

\section{METHODS}

\subsection{Vegetative Material}

The moss was taken from a wetland in Quillaipe (4131'43.89'S South Latitude,

Departamento de Ciencias Vegetales, Facultad de Agronomía e Ingeniería Forestal, Pontificia Universidad Católica de Chile, Avenida Vicuña Mackenna 4860, Macul, Santiago, Chile, Tel.: 52-02-3545726, Fax: 52-02-3545726, E-mail: gmonten@uc.cl 
$72^{\circ} 44^{\prime} 43.63$ 'W West Longitude) in the province of Llanquihue in the Los Lagos Region of Chile.

2.2. Preparation of ethanol extract of $S$. magellanicum resuspended in distilled water

Six point six grams of $S$. magellanicum were processed, dried and crushed using a Wathman $\mathrm{N}^{\circ} 2$ paper filter bag. The continuous extraction was performed in the Soxhlet apparatus using $250 \mathrm{~mL}$ of ethanol $80 \% \mathrm{v} / \mathrm{v}$ for 3 hours. The extract was distilled at reduced pressure in a rotating evaporator at $45{ }^{\circ} \mathrm{C}$ (Del Valle y Valdevenito, 1999). The extract was suspended in $2 \mathrm{~mL}$ of ethanol, passing it through a chromatographic column of Amberlite XAD-2 (200mm in height, $20 \mathrm{~mm}$ in diameter). The graduated cylinder was filled with $200 \mathrm{~mL}$ of distilled water, discarding the overflowing fraction. Afterwards, the graduated cylinder was filled with $200 \mathrm{~mL}$ of $100 \%$ ethanol (J.T. Baker®, HPLC grade). This was done in order to obtain the phenolic compounds that are found adhering to the chromatographic column. This mixture was dried out with a rotating evaporator. The dry extract was suspended in $3 \mathrm{~mL}$ of triple distilled water (Montenegro and Salas, 2006; Montenegro and Salas, 2007). The extract was sterilized by filtering with a syringe through filter paper with a pore size of $0.2 \mu \mathrm{m}$ (Orange ${ }^{\circledR}$ Scientific, Gyro disc CA-PC). The final concentration of the extract was $6.2 \mathrm{mg} / \mathrm{mL}$.

The absence of microorganisms in the extract was verified by seeding $100 \mu \mathrm{L}$ of extract in Petri dishes prepared with Soy Agar Trypticase and then incubated for 48 hours at $37^{\circ} \mathrm{C}$ in an incubator. There was no detection of bacterial colony growth; and the assay was done three times.

2.3. S. magellanicum extract effects on the in vitro growth of $G(-)$ and $G(+)$ bacteria.

The study was made with the bacterial culture collection of the Departamento de Ciencias Vegetales, Facultad de Agronomía e Ingeniería Forestal, Pontificia Universidad Católica de Chile. The stock G (-) bacteria studied were: Azotobacter vinelandii, Erwinia carotovora subsp. carotovora, Enterobacter aerogenes ATCC 13048 (American Type Culture Collection), Escherichia coli ATCC 25922, Pseudomonas aeruginosa ATCC 27853, Salmonella typhi STH 2370, and Vibrio cholerae ISP (isolated from a collection from the Instituto de Salud Pública de Chile). The $\mathrm{G}(+)$ bacteria studied were: Staphylococcus aureus subsp. aureus ATCC 25923 and Streptococcus type $\beta$. The bacterial cultures were kept isolated in Petri dishes with Soy Agar Trypticase (BBLTM Trypticase $^{\mathrm{TM}}$ Soy Broth and Agar) in an incubator in darkness at $37^{\circ} \mathrm{C}$ for 48 hours. The aim was to allow bacterial multiplication until the moment of use.

\subsection{Determination of the minimal concentration of the extract for bacterial growth inhibition (MIC)}

The determination of MIC is defined as the minimal extract concentration required inhibiting bacterial development. This was determined in micro plaques with 96 trays with a plane base of 8 rows $(\mathrm{A}-\mathrm{H})$ and 12 columns (Orange Scientific $\AA$ ). The micro dilution method was utilized (Pontino et al., 2006). In every well $150 \mu \mathrm{L}$ of Trypticase Soy Broth were placed (BBLTM Trypticase $^{\mathrm{TM}}$ Soy Broth), and then in the first column another $150 \mu \mathrm{L}$ of extract was added and then by half dilution was completed within the same column. Once the dilution was completed, $50 \mu \mathrm{L}$ of bacterial suspension of $1.5 \times 10^{6} \mathrm{ufc} / \mathrm{mL}$ in distilled water and equivalent to 75000 colony forming units per well, measured as 0.005 McFarland turbidity units (Biomeriux, Chile), were placed in every well except the control. The final extract dilution is expressed in $\mu \mathrm{g} / \mathrm{mL}$ of solution (Table 1). Some rows of the plaques were used for controls (without bacteria inoculums). The plaques were incubated at $37^{\circ} \mathrm{C}$ for 24 hours, and the bacterial growth within each well was evaluated according to turbidity.

\subsection{Determination of antioxidant properties} of $S$. magellanicum extract To determine the antioxidant properties of $S$. magellanicum extract, the reduction method of free radical 
DDPH (1,1-Diphenyl-2-2-picrylhydrazyl) was utilized. $950 \mu \mathrm{L}$ of DPPH solution in ethanol [(measured at $517 \mathrm{~nm}$ in a spectrometer, ESPECTR BID-1, Agilent 8453) with an absorbance of 0.6 (DO)] and50 $\mu \mathrm{L}$ of $S$. magellanicum ethanol extract were placed in quartz cubets. This measurement was repeated three times. The samples were homogenized and the absorbance of the mixture was measured immediately. The results were expressed in $\mathrm{mmol}$ of DDPH reduced $/ \mathrm{mL}$ of extract (Oszmianski et al., 2007; Liu et al., 2007). The phenolic compound concentration of $S$. magellanicum was evaluated according to the following methodology. An aliquot of 40 $\mu \mathrm{L}$ of extract was placed inside an Eppendorf tube ( $1.5 \mathrm{~mL}$ capacity), $100 \mu \mathrm{L}$ of reactive Folin-Ciocalteu and $560 \mu \mathrm{L}$ of distilled water was added to the tube and allowed to incubate for 15 minutes at room temperature. This procedure was repeated three times. After the incubation, $300 \mu \mathrm{L}$ of a calcium carbonate solution $(7 \%)$ was added to stop the reaction. Finally, the absorbance of the mixture was measured using a wavelength of $660 \mathrm{~nm}$ (Liu et al., 2007).

The characterization of the phenolic compounds was done using a reversedphase high performance liquid chromatographic (RP-HPLC, Agilent 1000 series, G1316A COLCOM, serial \# DE43646850) under the following conditions: $20 \mu \mathrm{L}$ of ethanol extract were injected for 20 minutes at $25^{\circ} \mathrm{C}$, pressure at 95 bar and a flow of $1 \mathrm{~mL} / \mathrm{min}$. A second characterization of the phenolic compounds was done using a reversed-phase high performance liquid chromatographic (RPHPLC, LaChrom serie 7000 Merck-Hitachi (Darmstadt, Germany), a Symmetry C18 Waters (Ireland), 4,6x250mm, 5mM, Precolumn: Symmetry C18 3.9 x 20 mm,5 $\mu \mathrm{m}$,$) under the following conditions: 20 \mu \mathrm{L}$ of ethanol extract were injected for 31 minutes at $40^{\circ} \mathrm{C}$, using phase mixture A:2\% formic acid mixture B: $32 \%$ formic acid: Methanol, 1:1 v/v mixture C: Methanol UV-wave Detection at $280 \mathrm{~nm}, 310 \mathrm{~nm}$ and $360 \mathrm{~nm}$. Compounds were quantified using peak area calculation, and partially identified using correlations between retention times.

\section{RESULTS}

3.1. Antibacterial activity of $S$. magellanicum ethanol extract: The $S$. magellanicum extract inhibited the in vitro growth of $V$. cholerae and $E$. carotovora subp. carotovora, E. coli, S. typhi and Streptococcus type $\beta$. The extract did not

TABLE 1

Antibacterial activity of the $S$. magellanicum ethanol extract, expressed in minimal extract concentration required to inhibit in vitro growth (MIC, $\mu \mathrm{g} / \mathrm{mL})$, on distinct isolated bacteria

\begin{tabular}{lcc}
\hline Bacteria & Bacterial Inhibition & $\begin{array}{c}\text { MIC of Sphagnum extract per bacteria } \\
\text { species }\end{array}$ \\
\hline Erwinia carotovora subsp. carotovora & + & 581.25 \\
Vibrio cholerae & + & 581.25 \\
Escherichia coli & + & 1162.5 \\
Salmonella typhi & + & 1162.5 \\
Streptococcus type $\beta$ & + & 1162.5 \\
Azotobacter vinelandii & - & - \\
Enterobacter aerogenes & - & - \\
Pseudomonas aeruginosa & - & - \\
Staphylococcus aureus subsp. aureus & - & - \\
\hline
\end{tabular}

+: Bacterial inhibition, -: No bacterial inhibition. 
inhibit the in vitro growth the bacteria $A$. vinelandii, E. aerogenes, $P$. aeruginosa and $S$. aureus subsp. aureus (Table 1).

\subsection{Antioxidant capacity, concentration} and characterization of phenolic compounds: The antioxidant capacity of the S. magellanicum extract was $0.179 \mathrm{mmol}$ of DPPH reduced $/ \mathrm{ml}$ extract, which is equal to $841 \mu$ mol TROLOX/100g of $S$. magellanicum with a total phenolic concentration of $4.22 \mathrm{mg}$ of total phenols/ $\mathrm{ml}$ of extract. Through high-pressure liquid chromatography (HPLC), the presence of vanillic acid, salicylic acid and other compounds was determined (Table 2).

TABLE 2

Phenolic compounds present in the ethanol extract of the native moss Sphagnum magellanicum, detected by RP-HPLC

\begin{tabular}{lcc}
\hline Name & Total/area[mAU*s] & Area \\
\hline Dyhidroxybenzoic & 330.90744 & 0.4665 \\
Chlorogenic acid & 395.94772 & 0.5582 \\
Sculetin & 95.11459 & 0.1341 \\
Caffeic acid & 133.92627 & 0.1888 \\
Syringic acid & 203.30341 & 0.2866 \\
Scopoletin & 76.30556 & 0.1076 \\
Vanillic acid & 567.51276 & 0.8001 \\
Salicylic acid & 88.05146 & 0.1241 \\
Total & & 2.6659 \\
\hline
\end{tabular}

\section{DISCUSSION}

The S. magellanicum extract had an important antibacterial effect against $E$. carotovora subsp. carotovora, V. cholerae, E. coli, S. typhi and Streptococcus type $\beta$, nevertheless, the extract concentrations required were significantly higher (500 to $1100 \mu \mathrm{g} / \mathrm{ml}$ ) than those reported for the ethanol extracts of eight dry species of native moss from India: Sphagnum junghuhnianum, Barbula javanica, Barbula arcuata, Brachythecium populeum, Brachythecium rutabulum, Minium marginatum and Entodon cf. rubicundus. The MIC in these ethanol extracts varied between 0.2 and $6.5 \mu \mathrm{g} / \mathrm{mL}$ (Singh et al.,
2006). This could indicate that the antibacterial agents of $S$. magellanicum are found in inferior quantities than those of the Indian moss, or could be due to different extraction systems. The promising results of this work correspond to the first study conducted on this native Chilean Bryophyte species and is a good start for continuing research involving other Bryophyte species with bacteriostatic properties. Furthermore, a moss extract whose habitat is the noncontaminated south of Chile makes it very attractive for use in the control of human and plant pathogens and as an organic food product.

The characterization by RP-HPLC (High Pressure Liquid Chromatography) determined the presence of phenolic compounds: Vanillic acid, syringic acid, chlorogenic acid, gallic acid, 3-4 hydroxybenzoic acid, caffeic acid, pcoumaric acid and salicylic acid. These components could be responsible for the antibacterial activity. Although the mechanisms involved are either not reported or not known in the majority of cases, this idea is based on the information found in the numerous publications reporting antibacterial activity in plant extracts and other organisms which also contain these phenolic compounds (Brent,2003; Cushnie and Lamb 1999). For example, vanillic acid has antibiotic properties against yeast that causes decomposition of foods such as Saccharomyces cerevisiae, Zygosaccharomyces bailii and Zygosaccharomyces rouxii; salicylic acid, the precursor to aspirin, inhibits the growth of Helicobacter pylori and Staphylococcus aureus (Kaellman, 1994).

The antioxidant capacity of the $S$. magellanicum extract obtained was 0.18 mmol of DDPH reduced $/ \mathrm{mL}$ of extract, equivalent in ORAC (Oxygen radical absorbance capacity assay) units to 841 $\mu \mathrm{mol}$ Trolox $/ 100 \mathrm{~g}$ units. This value of activity is inferior to the antioxidant capacity found in vegetative species for human consumption, such as garlic (Allium sativum) with 5.3-5umol TROLOX/100g and broccoli (Brassica oleracea $\mathrm{cv}$. italica) with $3.53 \mu \mathrm{mol}$ TROLOX/100 g. The 
antioxidant capacity for $S$. magellanicum is similar to the capacity reported in cabbage cultivar "Corazón de buey" (Brassica oleracea cv. capitata capitata), $856 \mu \mathrm{mol}$ of equivalents TROLOX/100g, and is superior to vegetables like pumpkin (Cucurbita pepo), $396 \mu$ mol TROLOX/ $100 \mathrm{~g}$ (Ninfali et al.,2005).

Examples of other plant extracts that have shown lower levels of antioxidant capacity, such as extracts from the root of the vegetative species, Filipendula vulgaris (Rosaceae), native to Poland, have an activity of $720 \mu \mathrm{mol}$ of TROLOX/100g equivilants (dry material). Waldsteinia geoides has an activity of $440 \mu \mathrm{mol}$ of Trolox/100g equivilants (dry material) (Osmianski et al., 2007).

Some studies have described the possibility of using Sphagnum magellanicum, as a source of fiber for foods, as a functional food, that is a food consumed not only for its nutritional characteristics, but also to achieve specific functions (Roberfroid, 2000). This is because of its total dietary fiber content, which reaches $77 \%$, a level much higher than found in other known fiber sources, such as rice shells, oats, barley and lupines (Villaroel et al., 2002). This study showed that Chilean native moss $S$. magellanicum has antibacterial and antioxidant properties.

\section{ACKNOWLEDGMENTS}

Financed by Fondecyt Project 1060535 to G. Montenegro, Fundación Copec-PUC TC006 to G. Montenegro and Fundación Copec-PUC TC026 to M.F Díaz

\section{REFERENCES}

ATAlAH S, URTEAGA C, REBOLlEDO A (1999) Patrones alimentarios y de actividad física en escolares de la Región de Aysén. Rev Chil Pediatr 70: 483-490
BASILE A, GIORDANO S, LÓPEZ-SAEZ J, COBIANCHI R (1999) Antibacterial activity of pure flavonoids isolated from mosses. Phytochemistry 52: 1479-1482

BRENT C (2003) Antimicobacterial natural products. Nat Prod Rep 20: 535-557

CUSHNIE T, LAMB A (2005) Antimicrobial activity of flavonoids. Int. J. Antimicrob. Agents 26: 343-356

DEL VALLE M, VALDEVENITO N (1999) en Mediciones y Métodos de Uso Común en el Laboratorio Químico. Primera edición, Universidad Católica de Chile: Santiago. 1999; 200 pp

FITZGERALD D, STRATFORD M, NARBAD A (2003) Analysis of the inhibition of food spoilage yeasts by vanillin. International Journal of Food Microbiology 86: $113-122$

KAELLMAN S (1994) Salicylic compounds and antibacterial activity in wild plants. Svensk Botanisk Tidskrift. 1994; 88: 97-101

LIU X, ARDO S, BUNNING M, PARRY J, ZHOU K, STUSHNOFF C, STONIKER F, YU L, KENDALL P (2007) Total phenolic content and DPPHd radical scavenging activity of lettuce (Lactuca sativa L.) grown in Colorado. LWT 40: 552-557

MONTENEGRO G, SALAS F (2006) Composición natural en base a extracto de mieles monoflorales chilenas provenientes de especies vegetales nativas para el control de infecciones bacterianas en vegetales en general, Patente Chilena, NCH 1069-06

MONTENEGRO G, SALAS F (2007) Natural composition based on Chilean monofloral honey extract from native vegetable species for bacterial infection control in vegetables and flowers. European Patent EP 1852017

NINFALI P, MEA G, GIORGINI S, ROCCHI M, BACCHIOCCA M (2005) Antioxidant capacity of vegetables, spices and dressings relevant to nutrition. British Journal of Nutrition 93: 257-266

OSZMIANSKI J, WOJDYLO A, LAMER-ZARAWSKA, SWAIDER K (2007)Antioxidant tannins from Rosaceae plant roots. Food Chem 100: 579-583

PONTINO M, DI GIULIO B, FERNANDEZ C (2006) Evaluation of a colorimetric micromethod for determining the minimal inhibitory concentration of antibiotics against Mycobacterium tuberculosis. Rev Argent Microbiol 38(3): 145-151

ROBERFROID M (2000) Concepts and strategy of functional food science: the European perspective". Am J Clin Nutr 71: 1660-1664

SINGH M, RAWAT A, GOVINDARAJAN R (2006) Antimicrobial activity of some Indian mosses. Fitoterapia 78: 156-158

VAN BREEMEN (1995) How sphagnum bogs down others plants. Trece 10: 270-275

VILLARROEL M, BIOLLEY E, YAÑEZ E (2002) Caracterización químico nutricional del musgo Sphagnum magellanicum. ALAN 52: 393-399

WANG W, WONG W, DAILIDIENE D, BERG D, GU Q, LAI K, LAM S, WANG B (2003) Aspirin inhibits the growth of Helicobacter pylori and enhances its susceptibility to antimicrobial agents. Gut 52: 490-495 
